\title{
Mass Balance Studies of the Glaciers in Hidden Valley, Mukut Himal*
}

\author{
Yoshiyuki Fujii**, Masayoshi Nakawo*** and Madan L. Shrestha****
}

\begin{abstract}
Accumulation and ablation measurements and stratigraphic studies were carried out on the Rikha Samba Glacier and Glacier G 3 in Hidden Valley, Mukut Himal during the monsoon season of 1974. The summer balance over the whole area of the Rikha Samba Glacier was slightly positive. The winter snow layer observed as a dirt layer in a pit was so thin that the summer balance approximate the net balance. The total amount of precipitation over the area above the firn line in the glacier basin was very close to the summer balance over the accumulation area. The change from snow to ice occurred due to the formation of columnar ice with parallel projections to the surface in firn by the daily melting-refreezing cycle.
\end{abstract}

\section{Introduction}

The glaciers in Hidden Valley (see the map in Fig. 2 of Higuchi (1976)) are on the northern side of the Great Himalayas where the precipitation $\mathrm{i}^{\mathrm{s}}$ low but still under the influence of the monsoon (Shrestha et al., 1976). In comparison with the glaciers on the southern side, they generally exist at a higher elevation and have a smaller size. It can be considered that the difference between the glaciers on northern and southern sides of the Great Himalayas is due to the difference in climatic conditions, particulaly the precipitation.

The studies of the glaciers on the northern side of the Himalayas have been neglected with a few exceptions (Watanabe et al., 1967; Hsieh et al., 1975). Observations of accumulation and ablation at the Rikha Samba Glacier and Glacier G 3, and stratigraphic studies of the surface layer in the accumulation area of the Rikha Samba

* Glaciological Expedition to Nepal, Contribution No. 7

** Water Research Institute, Nagoya University (present address, National Institute of Polar Research, Kaga 1-chome, Itabashiku, Tokyo 173).

*** The Institute of Low Temperature Science, Hokkaido University, Sapporo 060.

**** Meteorological Service, Department of Irrigation, Hydrology and Meteorology, Ministry of Food, Agriculture and Irrigation, Kathmandu, NEPAL.
Glacier were carried out during the monsoon season of 1974.

The Rikha Samba Glacier has an area of 4.81 $\mathrm{km}^{2}$ and an altitudinal span from $5245 \mathrm{~m}$ to 5985 $\mathrm{m}$, which makes it the largest glacier in Hidden Valley. The Rikha Samba Glacier is a valley glacier while Glacier G 3 lies on the ridge of Tukche Peak $(6915 \mathrm{~m})$ and descends down to a cirque below $5550 \mathrm{~m}$. Glacier $\mathrm{G} 3$ has an area of $0.62 \mathrm{~km}^{2}$. Its highest point is the top of the small peak $(6125 \mathrm{~m})$, and the lowest point the bottom of the cirque at $5300 \mathrm{~m}$.

Such a glacier without an accumulation basin as a reservoir of snow as Glacier G 3 is one of the typical forms of the glaciers on the northern side of the Great Himalayas; Glaciers G 1, G 7, G 9 and G 10 can be classified into this type.

\section{Measurements of accumulation and ablation}

Measurements of accumulation and ablation were made on the Rikha Samba Glacier and Glacier $\mathrm{G} 3$ by the stake method.

Twenty accumulation and ablation stakes, 4 stakes per $\mathrm{hm}^{2}$, were set in the area between $5265 \mathrm{~m}$ and $5730 \mathrm{~m}$ of the Rikha Samba Glacier along two lines across the ablation and accumulation areas and along one line near the firn line as shown in Fig. 1.

According to Hoinkes (1964), 10 stakes per $\mathrm{km}^{2}$ are necessary for accurate assessment of the mass balance of a glacier. The number of the stakes in the preesent case is less than 10, but 


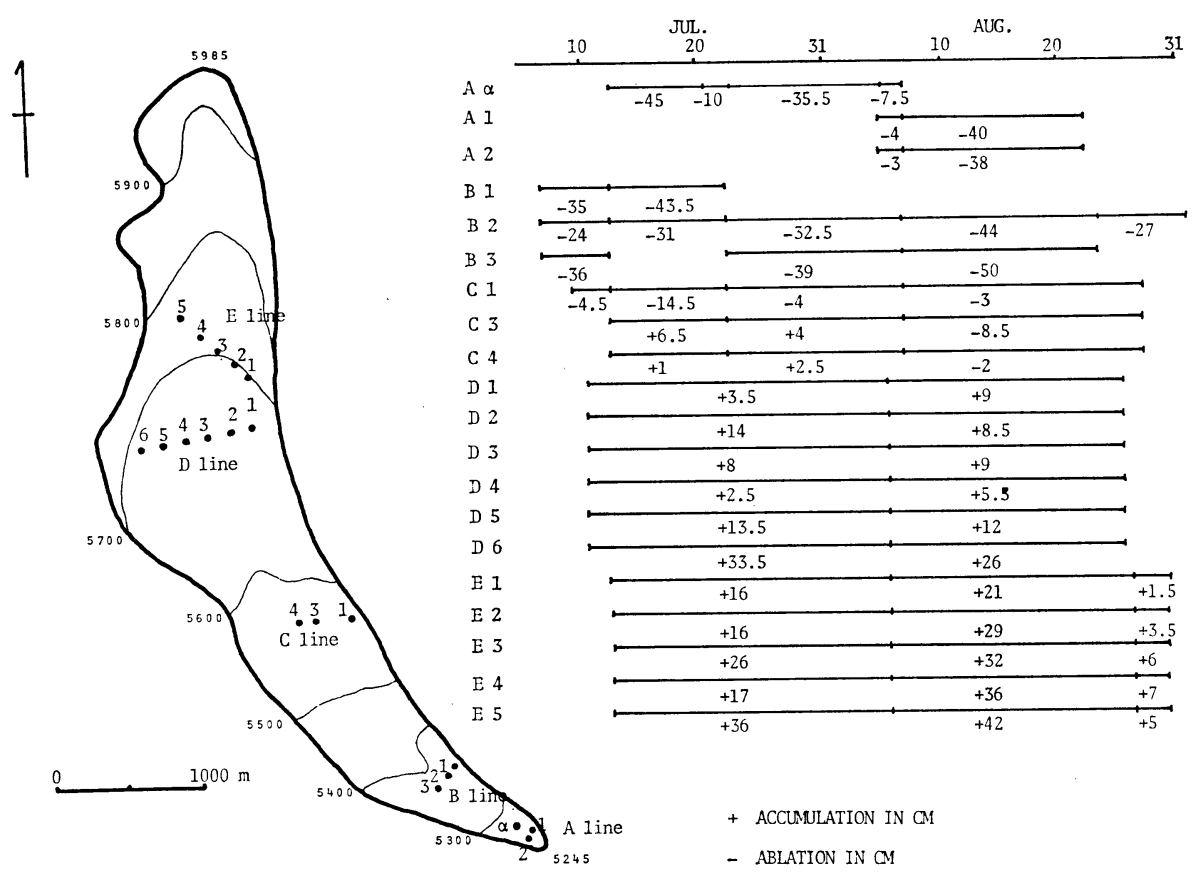

Fig. 1. Positions of accumulation and ablation stakes and changes of the height of the glacier surface at each stake set on the Rikha Samba Glacier, showing accumulation + and ablation - in $\mathrm{cm}$.

the shape of the Rikha Samba Glacier is so simple that it may be possible to estimate the mass balance without a large error.

Measurements of these stakes were made 3 to 6 times during the period from early July to the end of August, 1974. The observation results are shown in Fig. 1. In the right part of Fig. 1, holizontal lines indicate the observation period, and pauses of the line indicate the date of the observation. The numbers between two pauses indicate the change of the height of glacier surface, namely, accumulation $(+)$ and ablation $(-)$ in $\mathrm{cm}$.

As seen in Fig. 1, the ablation occurred along the lines $A$ and $B$ at the rate of about $-3 \mathrm{~cm} /$ day on the average, and -3.5 to $-5.5 \mathrm{~cm} /$ day in early July. Accumulation occured along the lines $\mathrm{D}$ and $\mathrm{E}$ at the rate of between +0.5 and $+1.5 \mathrm{~cm} /$ day in this observation period.

With a few exceptions, the accumulation was less on the east side and in the lower part of the accumulation area; for instance, at the two stakes nearest the east margin along the lines D and $\mathrm{E}$, the accumulation was 73 and 76 per cent of the mean accumulation along each line. As the west margin of the accumulation area is located on the lee side of a mountain ridge, the higher accumulation rate may be due to the wind deposit of snow. Besides, the ablation rate has

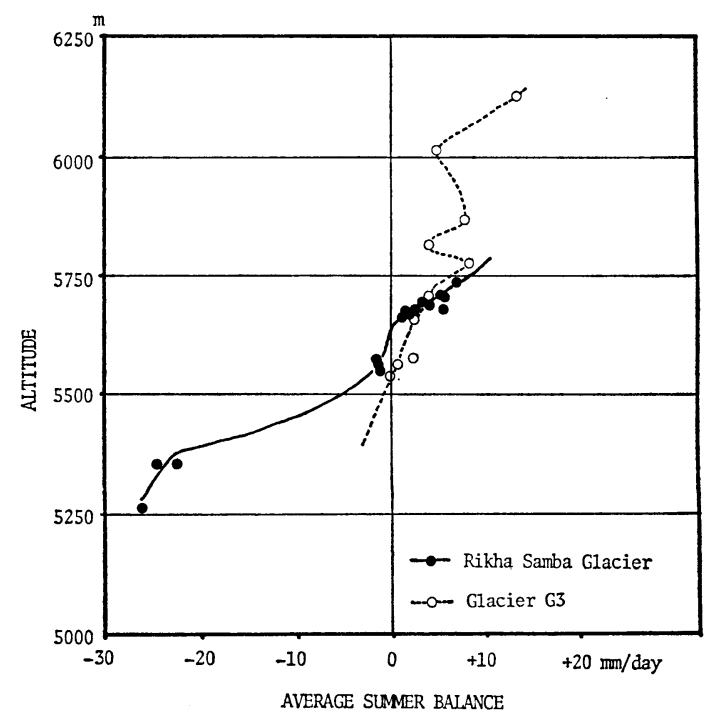

Fig. 2. Altitudinal variation in net accumulation and ablation, shown by a solid line for the Rikha Samba Glacier and by a dashed line for Glacier G 3. 
a tendency to be greater in the lower part of the ablation area but this is not so obvious.

On Glacier G 3, 10 stakes were set along a line with 30 to $140 \mathrm{~m}$ altitudinal span from 5533 $\mathrm{m}$ to $6121 \mathrm{~m}$. These stakes were set on July 23 and the measurements were made on September 2, after 41 days.

Fig. 2 shows the net accumulation and ablation against elevation observed on the Rihha Samba Glacier and Glacier $G$ 3. These amounts are given as a value of the daily mean in each observation period. With increasing height, the amount of net accumulation tends to increase, but the increasing rate of net accumulation against altitude on Glacier G3 is extremely small in comparison with the case of the Rikha Samba Glacier.

Since Glacier G 3 is located on the northern ridge of Tukche Peak and its surface is well exposed to the strong prevailing wind coming up along Mayandhi Khola on the covex slope, the accumulation pattern is largely controlled by the wind. The various amounts of accumulation were observed in the area above $5700 \mathrm{~m}$, where the surface of this glacier is convex.
On the other hand, as the Rikha Samba Glacier is in a valley protected against the prevailing wind coming up along Mukut Khola, the wind deposit of snow should have a large effect on the accumulation of snow on this glacier surface. The maximum net accumulation was observed at stake E-5 $(5729 \mathrm{~m})$ and was 1.7 times the total precipitation observed in the same period at Hidden Valley Base Camp (5055 m).

\section{Stratigraphic studies}

Few studies (Hsieh et al., 1975) have been done on the processes of glacier ice formation on the glaciers on the northern side of Himalayas. Therefore, pit studies for stratigraphic observation of the surface snow layer were carried out at each stake on the Rikha Samba Glacier.

Fig. 3 shows some of the results obtained by pit studies during the period from early July to the end of August.

Since the boundary between firn and ice on the glacier surface was near C-line in Fig. 1 at the end of August, the height of the firn line was estimated at about $5550 \mathrm{~m}$.

In the ablation area below $5400 \mathrm{~m}$, glacier ice
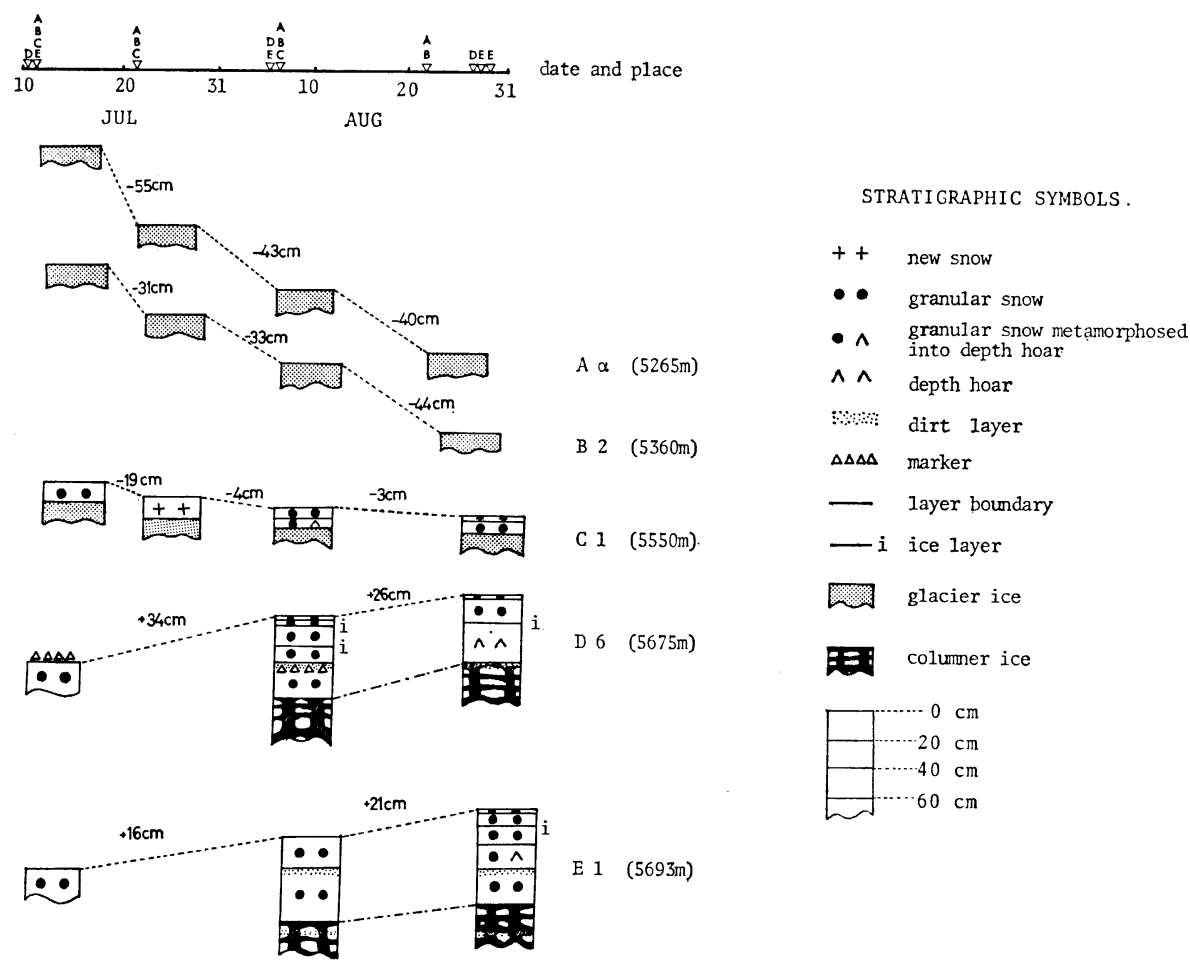

Fig. 3. Stratigraphy of the surface snow layer of the Rikha Samba Glacier during the observation period from early July to the end of August, 1974. 
was exposed throughout the observation period and lowering of its surface occurred at a rate of $130 \mathrm{~cm}$ to $150 \mathrm{~cm}$ for about 45 days. The glacier surface near the firn line was covered by a granular or new snow layer of about $10 \sim 20$ $\mathrm{cm}$ thick, but the surface of the glacier ice under the snow layer was lowering slightly by melting.

In the accumulation area, the change from snow to glacier ice occurred due to the formation of columnar ice with projections parallel to the surface in firn. The projections of columnar ice, white in color with air bubbles, was formed by the refreezing of meltwater percolated and spread out horizontally along a relatively impermeable layer in firn.

As seen in Fig. 3, the level of columnar ice rose at a rate of between $15 \mathrm{~cm}$ and $30 \mathrm{~cm}$ for 20 days. This shows that the process of meltingpercolating-refreezing occurred frequently and accelerated the formation of the columnar ice. According to Hsieh et al. (1975), ice formation by such a process was observed in the area between the snow line and the summit of Mt. Jolmo Lungma (Mt. Everest, $8848 \mathrm{~m}$ ).

The wet layers of depth hoar were observed in some pits, as a transformation of recentlyfallen snow, as shown at the stake D-6 in Fig. 3. Since depth hoar is formed under the condition of a strong vertical temperature gradient, the formation of this depth hoar can be explained by the radiative cooling of the glacier surface after melting of snow during the daytime.

The formation of columnar ice and depth hoar suggests that the melting-percolating-refreezing cycle occurs daily during monsoon period.

One or two dirt layers were recognized in the pits in the accumulation area. The first dirt layer, nearest to the surface, was formed at about the same level as the surface observed in early July. For instance, the markers scattered on the surface at stake D- 6 on July 11 were found on August 6 in the dirt layer, $32 \mathrm{~cm}$ below the surface, which was the surface observed on July 11. The second dirt layer was at a depth of $75 \mathrm{~cm}$ below the surface in the pit at stake E-1 on August 27. It is, therefore, clear that the first dirt layer was the surface formed before early July.

Though the weather record in the season previous to the monsoon of 1974 is not available in Hidden Valley, the precipitation in the period from November of 1973 to June of 1974 was only few tens of $\mathrm{mm}$ at the nearest weather stations to Hidden Valley, Jomosom $(2615 \mathrm{~m})$ and Thakmarpha $(2545 \mathrm{~m})$. The dirt layer with a thickness of $3 \sim 4 \mathrm{~cm}$, therefore, should be formed in this dry season containing the soil particles blown from the dry ground in the surface snow layer.

In comparison with the net accumulation in this observation period, $+15 \sim 20 \mathrm{~g} \cdot \mathrm{cm}^{-2}$, in the accumulation area along $\mathrm{D}$ and $\mathrm{E}$ lines, the net accumulation in the previous period from winter to pre-monsoon season, $+1.2 \sim 1.6 \mathrm{~g} \cdot \mathrm{cm}^{-2}$, is so small that the summer balance in the monsoon period approximates the net balance.

\section{Mass balance of the Rikha Samba Glacier}

In the case of glaciers in the Nepal Himalayas, accumulation and ablation occur mainly in summer under the influence of the monsoon. The summer balance of the glacier, therefore, can be considered as nearly equal to the net balance as mentioned in section 3 .

Fig. 4 shows the summer balance at the Rikha Samba Glacier during the period from July to August, 1974. In this mass balance diagram, the summer balance (bs) and glacier area distribution ( $\Delta \mathrm{s})$ curves are plotted against elevation. The resulting areal values of Summer Balance (bs. $\Delta \mathrm{s}$ ) against ten altitudinal apans are given as histograms. The altitudinal distribution of precipitation $(P)$ obtained in this observation period along the lateral moraine of the glacier is also illustrated by a solid line.

Since the change of precipitation with elevation is very small, it may be possible to take the total amount of $200 \mathrm{~mm}$ as the average precipitation in the glacier basin during the observation period. Therefore, the total amount of precipitation over the area above the firn line on the glacier, $3.6 \mathrm{~km}^{2}$, and in the glacier basin, $6.3 \mathrm{~km}^{2}$, were calculated to be $0.7 \times 10^{6} \mathrm{~m}^{3}$ and $1.2 \times 10^{6} \mathrm{~m}^{3}$ respectively.

In comparison with the total amount of precipitation over the area above the firn line on the glacier, that in the glacier basin agrees well with the summer balance over the accumulation area, $+1.22 \times 10^{6} \mathrm{~m}^{3}$. This shows that the falling snow and/or deposited snow in the non-glacier area in the glacier basin above the firn line is transported to the accumulation area by wind. The 


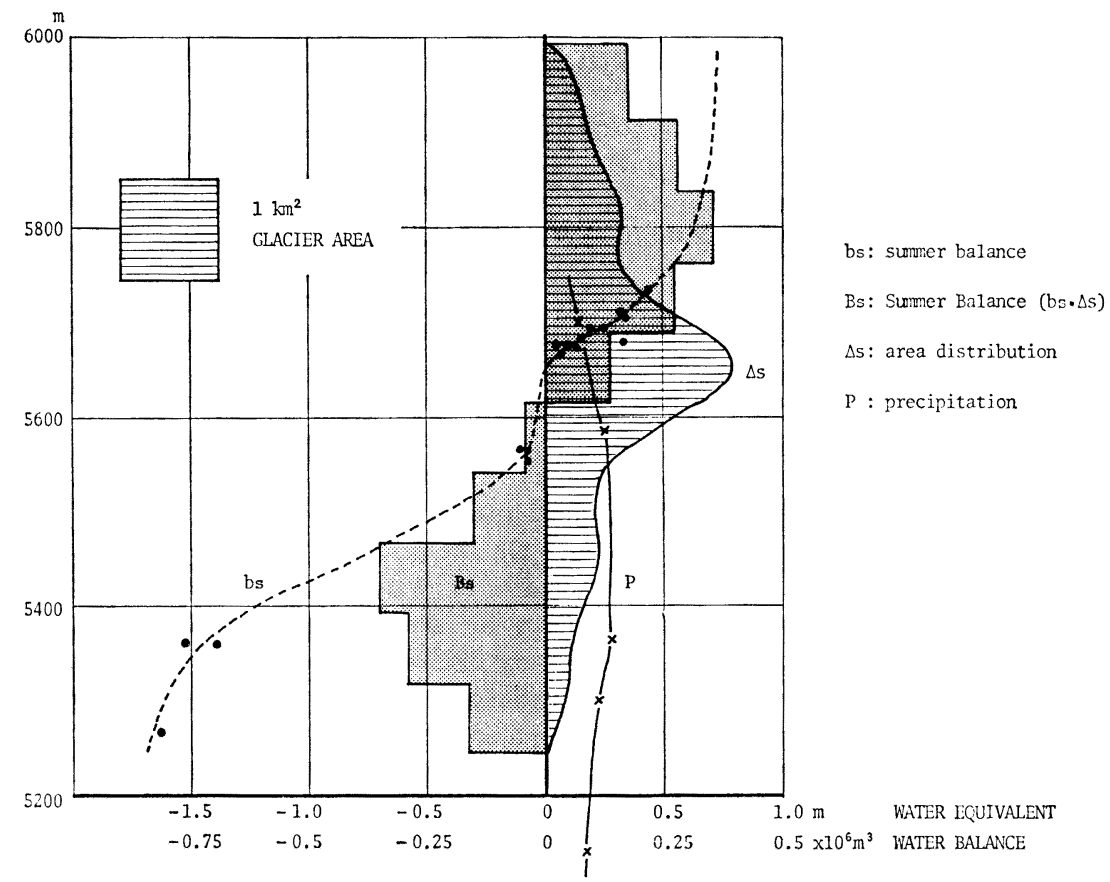

Fig. 4. The mass balance diagram of the Rikha Samba Glacier for the summer of 1974 .

amount may be about $0.5 \times 10^{6} \mathrm{~m}^{2}$, namely about $40 \%$ of the summer balance over the accumulation area, given by the difference of the total precipitation over area above the firn line on the glacier, $0.7 \times 10^{6} \mathrm{~m}^{3}$, from that in the glacier basin, $1.2 \times 10^{6} \mathrm{~m}^{3}$.

Besides, the summer balance over the ablation area was negative and amounted to $-0.99 \times 10^{6}$ $\mathrm{m}^{3}$, namely about $-8.3 \mathrm{~g} \cdot \mathrm{cm}^{-2}$.

The Summer Balance over the whole area of the glacier (Bs) was, therefore, positive and amounted to $0.23 \times 10^{6} \mathrm{~m}^{3}$ of water equivalent. The average summer balance was a gain of 4.8 $\mathrm{g} \cdot \mathrm{cm}^{-2}$ over the whole area of the glacier, 4.81 $\mathrm{km}^{2}$.

In the case of such a glacier with the widest part near the equilibrium line, however, small change in climatic conditions may have a large effect on the mass balance of the glacier.

\section{References}

Higuchi, K. (1976): Outline of the Glacioligical Expedition to Nepal. in this issue.
Hoinkes, H.G. (1964): Glacial meteorology. in Odihaw, H., ed. Research in Geophysics, Vol. 2, Solid earth and interface phenomena, Cambridge, Mass., Massachusetts Institute of Technology Press, 391-424.

Hsieh, T. et al. (1975): Basic features of the glaciers of the Mt. Jolmo Lungma region, southern part of the Tibet autonomous region, China. Division of Glaciology, Lanchow Institute of Glaciology, Cryopedology and Desert Research, Academica Sinica, Scientia Sinica, Vol. 18, No. 1, 106-130.

Shrestha, M.L., Fujii, Y. and Nakawo, M. (1976): The climate of Hidden Valley during the monsoon, 1974. in this issue.

Watanabe, O., Endo, Y. and Ishida, T. (1967): Himalaya no hyoga ni tsuite (Glaciers and Glaciations in the Nepal Himalaya, mainly on the results of field research on two glaciers in the Nepal Himalaya). Low Temperature Sicence, Ser. A, 25, 197-219. 